Canadian University Music Review

Revue de musique des universités canadiennes

\title{
Two Unpublished Instrumental Works by Healey Willan
}

\section{Frederick R.C. Clarke}

Numéro 1, 1980

URI : https://id.erudit.org/iderudit/1013731ar

DOI : https://doi.org/10.7202/1013731ar

Aller au sommaire du numéro

Éditeur(s)

Canadian University Music Society / Société de musique des universités

canadiennes

ISSN

0710-0353 (imprimé)

2291-2436 (numérique)

Découvrir la revue

Citer cet article

Clarke, F. R. (1980). Two Unpublished Instrumental Works by Healey Willan. Canadian University Music Review / Revue de musique des universités

canadiennes, (1), 1-7. https://doi.org/10.7202/1013731ar

All Rights Reserved (C Canadian University Music Society / Société de musique des universités canadiennes, 1980
Ce document est protégé par la loi sur le droit d'auteur. L'utilisation des services d’Érudit (y compris la reproduction) est assujettie à sa politique d'utilisation que vous pouvez consulter en ligne.

https://apropos.erudit.org/fr/usagers/politique-dutilisation/ 


\title{
TWO UNPUBLISHED INSTRUMENTAL WORKS BY HEALEY WILLAN
}

\author{
Frederick R.C. Clarke
}

During 1980 the centenary of the birth of Healey Willan (1880-1968) is being observed and many performances of the composer's major works are taking place along with presentations of a number of unpublished and largely unknown works. Two of these latter are the subject of this paper: the first movement (Prelude) of the unfinished Suite for Organ and the single completed movement of the Sonata No. 3 for Violin and Piano.

One of Willan's most imaginative periods of instrumental composition occurred during the years immediately preceding and following his move to Canada in 1913. Many of the composer's most significant instrumental pieces date from this time (1908-16), notably the Prelude and Fugue in C Minor and the Introduction, Passacaglia and Fugue in E flat Minor (undoubtedly his .two greatest organ works), the Variations and Epilogue for two pianos, the Piano Trio in B Minor, and the Sonata No. 1 in E Minor for Violin and Piano.

After 1916, Willan's next large-scale instrumental venture was a projected Suite for Organ in four movements. Only the first movement of the work, the Prelude, was completed at the time (August 8, 1918). ${ }^{1}$ This fine Prelude has remained in manuscript and appears to have received its first performance only recently.

The title "Prelude" for the completed first movement of the Suite is somewhat misleading in that it gives little clue to the scope and size of the piece (which covers eleven pages of manuscript). It is known that Willan greatly admired the twenty organ sonatas of Josef Rheinberger and played a number of them himself. Rheinberger gave the title of "Prelude" to many of the first movements of his sonatas and it may be in this 
context that Willan is using the name here. Certainly Willan's piece is equivalent in magnitude and substance to any opening movement of a Rheinberger sonata.

In formal design the Prelude is similar to some of the early Baroque organ toccatas, with a freely rhapsodic opening section, a fugal middle section, and a final section again in free style. Example 1 illustrates the general style of the rhapsodic opening section. Within this seven-measure extract are contained the three main figures (marked $a, b$, and $c$ ) on which this section is built. Figure $a$ is the flourish with which the movement commences, initially in A minor, and then in C sharp minor as shown; figure $b$ is an example of Willan's colorful progressions of little-related chords, held together in this case by a descending chromatic scale in the upper part (a device - stemming from Wagner - which Willan had already used for the opening of his dramatic cantata Cleopatra of 1907); figure $c$, which reveals the influence of Franck and Rheinberger, but cannot be said to be an actual copy of either, is obviously useful for the working of sequential build-ups and developments (and is so employed).

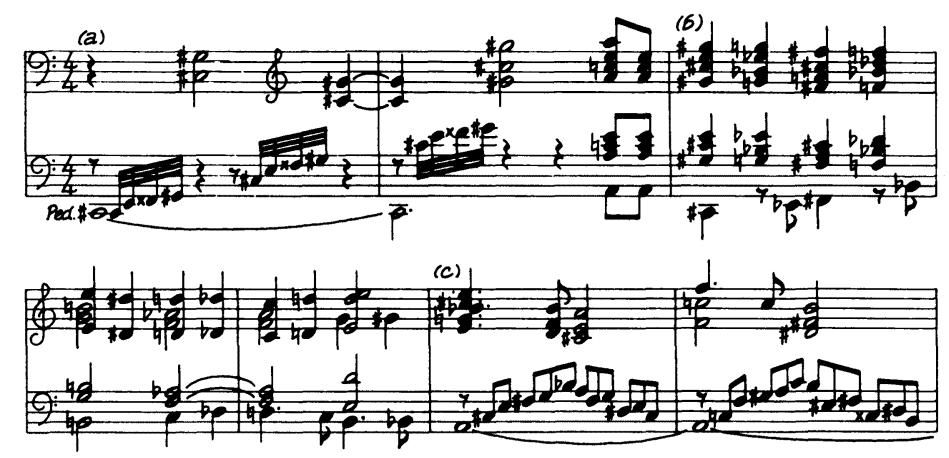

Example 1. Willan: Prelude from Suite for Organ (1918), opening section.

The fugal middle section of the Prelude, commencing in C major, uses one of Willan's most progressive fugue subjects (Ex. 2):

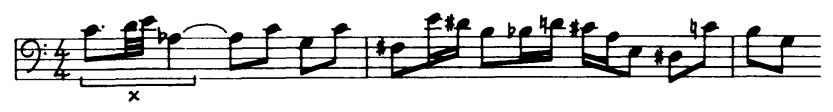

Example 2. Prelude, fugue subject. 
The subject narrowly misses using all twelve notes - only the $\mathrm{F}$ is missing. There is a four-voice exposition, though the part-writing is treated rather freely after the third entry, and the fourth entry is incomplete. At the third entry a countermotive appears - shown in Example 3 and marked $y$ - which is used subsequently in episodes:

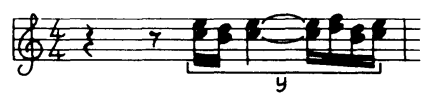

Example 3. Prelude, fugal counter-motive.

The opening figure of the fugue subject (marked $x$ in Ex. 2) is also employed extensively in the episodes. The use of both the $x$ and $y$ motives in an episodical passage is illustrated in Example 4:

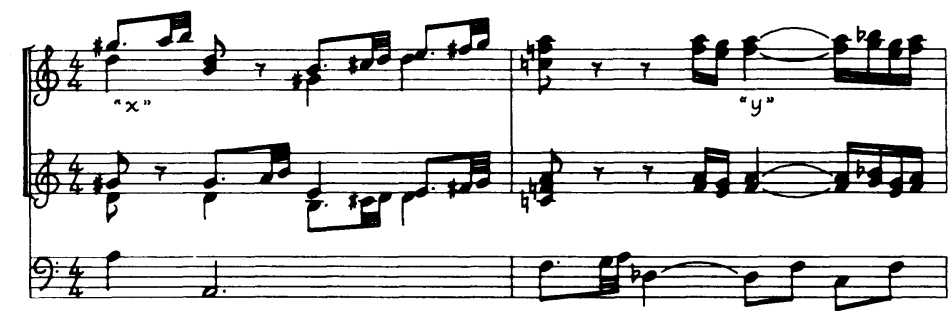

Example 4. Prelude, $x$ and $y$ motives.

Willan's use of the r. rhythm here is reminiscent of Rheinberger's treatment of the same figure in his Sonata No. 6 in E flat Minor for Organ (see Ex. 5). Significantly this sonata first appeared on Willan's recital programs in 1916.

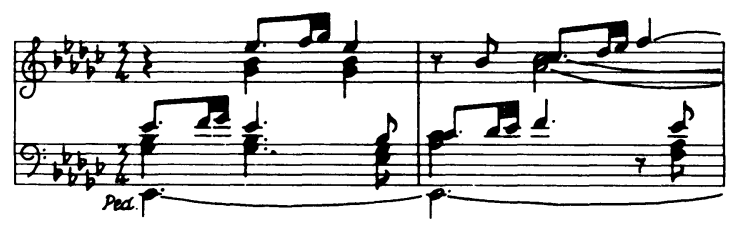

Example 5. Rheinberger: Sonata No. 6 in E flat Minor for Organ, Op. 119 (1880), rhythmic motive.

Following its exposition, the fugue proceeds very freely, with only one full statement of the subject (in E major) in its middle section. 
There is no final section to the fugue (i.e., a return to $C$ major), but in its place a return to the main tonality of the whole movement, A minor, and a concluding section consisting of a repetition of part of the first section, with some variation (e.g., the left-hand triplet eighths of Ex. 1c now become sixteenths). A coda, based on the $x$ motive from the fugue subject and figure $a$ from the opening section, concludes the piece amidst a certain amount of bravura solo pedal work in true organ toccata style.

Why this work was never published by the composer remains a mystery, since it is an exciting piece and of superior musical value to much of the later organ music which the composer did publish. The manuscript reveals no indication of having been used for performance (i.e., no registration marks, dog-ears, etc.) and no evidence has come to light that Willan ever played it publicly. There is a complete absence of tempo indications, dynamic markings, and the like in the manuscript; just the bare notes are there. Nevertheless, anyone familiar with Willan's organ style would have little difficulty creating a satisfactory interpretation of this music.

The other unknown Willan instrumental piece under consideration here is the single completed movement of a projected Sonata No. 3 for Violin and Piano. Having already completed two sonat as for this combination - in 1916 and 1921, respectively - both of which were subsequently published, Willan started on a third in 1922. Unfortunately the Sonata No. 3 was apparently not finished, although there is always the possibility that Willan was using the term "sonata" in its older sense (i.e., simply a piece that was played rather than sung) and that he titled the single movement accordingly and considered the work completed.

The completed movement is an Adagio, yet its title page says simply, "Sonata No. 3, Violin and Piano," giving no indication that the Adagio is possibly the slow middle movement of a projected three- or four-movement work. Of course the composer might have been planning another sonata (like the Second Violin Sonata) using the Baroque slow-fast-slow-fast tempo scheme, which would account for the placement of the 
Adagio immediately after the title page. The only problem with this hypothesis is that, unlike the movements of the Second Violin Sonata, this Adagio (in B minor) is not at all Baroque in style. If it is in fact the complete sonata, or if it is the first of several projected movements, the title "Sonata No. 3 in B Minor" is appropriate. If, on the other hand, it was intended as a slow middle movement of a modern sonata, there is little likelihood that the missing outer movements would have been in the same key as the middle movement, and therefore the whole sonata would probably not have been in B minor (note that Willan's title page says ony "Sonata No. 3," making no mention of key). Finally, because of its length and the completeness of its structure, it is also most unlikely that this Adagio was intended to be only a slow introduction to a sonata-allegro movement.

The structure of the Adagio in B Minor is a modified sonata form. The exposition commences with a gentle rocking figure in the piano part, a quasi-siciliano pattern that tends to pervade the entire movement (Ex. 6). The main theme proper is a delightfully plaintive tune which has an almost Russian flavor (Ex. 7). The tune is repeated, punctuated by the siciliano motive, and then a bridge passage follows. This bridge section is based upon a figure from the main subject, and ends in $\mathrm{E}$ minor in preparation for the subsidiary subject (Ex. 8):

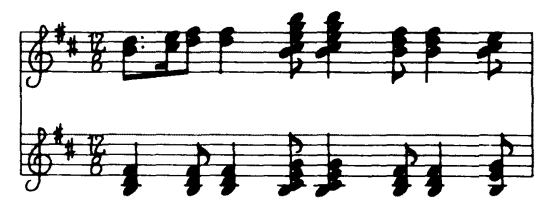

Example 6. Willan: Adagio in B Minor for Violin and Piano (1922), opening.

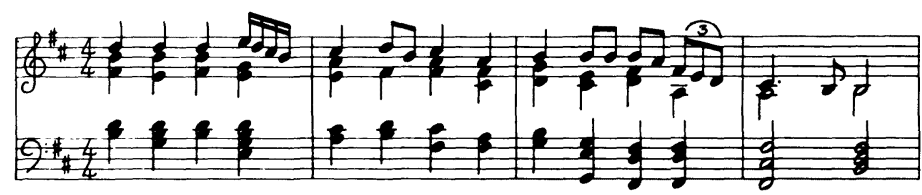

Example 7. Adagio in B Minor, first subject. 


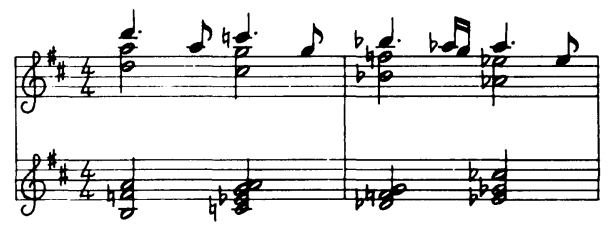

Example 8. Adagio in B Minor, second subject.

There is something of the flavor of Delius in the second theme section. The tonality is very fluid, but finally comes to rest in $\mathrm{E}$ major with a codetta-like passage over a combined tonic/dominant pedal.

As is not uncommon with slow movements in sonata form, there is no development section but merely a short linking passage (in $\mathrm{C}$ major) which contains a brief reference to the subsidiary theme and concludes with a quasi-recitativo passage for the violin. The home tonality of $\mathrm{B}$ minor returns with the recapitulation, which repeats the main subject in its entirety but alters and considerably lengthens the ensuing bridge passage, giving the impression of a partial development section based on the opening materials. The tonality ranges as far afield as $\mathrm{B}$ flat minor and $\mathrm{D}$ flat major. The subsidiary theme then makes its reappearance, followed by a short coda based on all previous material. The music seems very reluctant to settle home in $\mathrm{B}$ minor until the last three measures. It might be noted that the procedure of omitting the development at its usual place, and then placing developmental material between the first and second subjects of the recapitulation was used on occasion by Brahms (e.g., the finales of Symphonies Nos. 1 and 3).

The origins of the main thematic material of Willan's Adagio in B Minor (Exx. 6 \& 7) can be found in an unfinished sketch for a slow movement in $\mathrm{C}$ minor of a string quartet (B. 110). The sketch would appear to date from ca. 1905-10 and is one of many such sketches of unfinished symphonic and chamber works dating from that period. Willan's later treatment of the material is a considerable improvement over the sketch. The Adagio in B Minor (or, if one prefers, Sonata No. 3) of 1922 is an exquisite work, quite the equal of the Poem for strings and superior to the slow movements of either of the earlier sonatas for violin and piano. It shares with the Poem the inscription from W.B. Yeats, "And evening, full of linnet's wings," which, 
it might be noted, is taken from The Lake Isle of Innisfree, a poem which Willan set as a song (it appears as No. 4 of the six songs in the Healey Willan Song Album, No. 2, published in 1926). At the appearance of Yeats's line in the song, Willan quotes, in the piano part, a variant of the siciliano theme of the Adagio in B Minor (Ex. 6). Since the original manuscript of the song has been lost, the exact date of its composition is not known, and it cannot be determined whether the song or the Adagio came first.

Willan's Third Violin Sonata, whether it be complete in one movement or merely a torso, deserves to be better known. It has remained in manuscript and presumably unperformed until recently. ${ }^{2}$ Willan must have made at least two versions of the piece, since the existing manuscript of the violin part differs in a number of places (chiefly octave transposition) from the violin part that appears in the manuscript full score. The full score contains no bowing or expression marks of any sort, save for an indication of pianissimo at the opening. The separate manuscript of the violin part does exhibit a few markings, but these are by no means complete.

\section{NOTES}

1. In 1950 Willan published a Barcarolle for organ; the first thirty-four measures of this had been written in 1918 and intended for the Suite for Organ, but the piece was not completed until much later.

2. Private recordings of both the Organ Prelude and the Adagio in B Minor have been made by the author (organ and piano) and violinist Alanna Deptuch. 